\title{
HISTOLOGICAL AND HISTOCHEMICAL ASPECTS OF THE PENIAL GLANDS OF Girardia biapertura SLUYS, 1997 (PLATYHELMINTHES, TRICLADIDA, PALUDICOLA)
}

\author{
SOUZA, S. T. and LEAL-ZANCHET, A. M. \\ Instituto de Pesquisas de Planárias, Centro de Ciências da Saúde, Universidade do Vale do Rio dos Sinos, \\ CEP 93022-000, São Leopoldo, RS, Brazil \\ Correspondence to: Ana Maria Leal-Zanchet, Instituto de Pesquisas de Planárias, Centro de Ciências da Saúde, \\ Universidade do Vale do Rio dos Sinos, CEP 93022-000, São Leopoldo, RS, Brazil, e-mail: ipp@ cirrus.unisinos.br \\ Received September 11, 2001 - Accepted October 29, 2001 - Distributed August 31, 2002
}

(With 9 figures)

\begin{abstract}
Girardia biapertura was described with sperm ducts penetrating the penis bulb, subsequently opening separately at the tip of the penis papilla and receiving the abundant secretion of penial glands. In the present work, the penial glands of this species have been histologically and histochemically analysed, and four types of secretory cells are distinguished. The openings of the penial glands into the intrabulbar and intrapapillar sperm ducts, designated here as intrapenial ducts, allow for the distinction between three histologically differentiated regions. The most proximal region possibly corresponds to the bulbar cavity of other freshwater triclads whereas the median and distal portions correspond to the ejaculatory duct. The proximal region of the intrapenial ducts receives mainly the openings of a secretory cell type (type I) that produces a proteinaceous secretion. A second type of secretory cell (type II) that secretes neutral mucopolyssacharides opens into the median region of the intrapenial ducts. The distal portion of the ducts receives two types of secretory cells (types III and IV) which secret glycoprotein and glycosaminoglycans, respectively. Types III and IV open also directly into the male atrium through the epithelium of the penis papilla. A comparison with the results presented here and those of other authors for species of Girardia is provided and the importance of the study of the penial glands for taxonomic characterisation of freshwater triclads is emphasised.
\end{abstract}

Key words: secretory cells, histochemistry, flatworms, Dugesiidae.

\section{RESUMO}

Aspectos histológicos e histoquímicos das glândulas peniais de Giardia biapertura Sluys, 1997 (Platyhelminthes, tricladida, Paludicola)

A espécie Girardia biapertura apresenta, segundo sua descrição original, ductos espermáticos penetrando o bulbo penial e, subseqüentemente, desembocando separadamente na ponta da papila penial e recebendo abundante secreção das glândulas peniais. No presente trabalho, as glândulas peniais dessa espécie foram analisadas histológica e histoquimicamente, sendo constatados quatro tipos de células secretoras. A desembocadura das glândulas peniais nas porções intrabulbar e intrapapilar dos ductos espermáticos, aqui designados como ductos intrapeniais, permite diferenciar três regiões histologicamente distintas. A região mais proximal desses ductos provavelmente corresponde à cavidade bulbar, enquanto as porções média e distal, ao ducto ejaculatório de outros tricladidos. A região proximal dos ductos intrapeniais recebe principalmente a desembocadura de um tipo de célula secretora (tipo I), cuja secreção é protéica. Na região média dos ductos intrapeniais desemboca um segundo tipo de célula secretora (tipo II), contendo mucopolissacarídeos neutros. A porção mais distal dos ductos intrapeniais recebe a desembocadura de dois tipos de células secretoras (tipos III e IV) que secretam glicoproteína e glicosaminoglicanas, respectivamente. As células dos tipos III e IV desembocam, também, diretamente no átrio masculino através do epitélio de revestimento da papila penial. Comparam-se os resultados obtidos 
com aqueles de outros autores para espécies do gênero Girardia e enfatiza-se a importância do estudo das glândulas peniais para a caracterização taxonômica das espécies de tricladidos dulcícolas.

Palavras-chave: células secretoras, histoquímica, planárias, Dugesiidae.

\section{INTRODUCTION}

The histology and particularly the histochemistry of the glands of the copulatory apparatus of Dugesiidae Ball, 1974 are poorly known. With respect to species of the genus Girardia Ball, 1974, Fischlschweiger \& Clausnitzer (1984) and Fischlschweiger (1990) studied the ultrastructure of the female and male organs of G. tigrina (Girard, 1850), Moretto (1996) analysed the histology and the ultrastructure of the reproductive system of $G$. sanchezi (Hyman, 1959) and G. bonaerensis (Moretto, 1996), and Leal-Zanchet \& Hauser (1999) examined histological and histochemical aspects of the penial glands of G. schubarti (Marcus, 1946). Other, more taxonomic studies reported on the anatomy and histology of the reproductive organs of G. tigrina, G. schubarti, G. anderlani (Kawakatsu \& Hauser, 1983), G. arndti (Marcus, 1946), G. rincona (Marcus, 1954), G. festae (Borelli, 1898), and G. anceps (Kenk, 1930) (Kawakatsu et al., 1982, 1983a, b, 1984a, b, 1985, 1986; Sluys, 1992, 1996). However in these studies the glands of the reproductive system were only superficially described.

The species G. biapertura Sluys, 1997 that has been studied here shows a unique characteristic, not only in the genus Girardia, but in the Tricladida as a whole, in that the vasa deferentia open separately at the tip of the penis papilla (Sluys et al., 1997).

In the present work, a histological study characterising the types of penial glands of $G$. biapertura and analysing their distribution and their histochemical characteristics, was performed with the following three objectives: (1) to look for the occurrence of local differentiations along the intrapenial ducts (Sluys' intrabulbar vasa deferentia), (2) to support further studies on the physiology of the male copulatory organs, and (3) to contribute to the taxonomical characterisation of the species.

\section{MATERIAL AND METHODS}

Adult specimens of Girardia biapertura were collected from the type-locality, São Sebastião do Caí, Rio Grande do Sul, Brazil, and kept in a cold room at $18^{\circ} \mathrm{C}$. Whole worms were fixed in Lillie's $4 \%$ neutral formaldehyde (Romeis, 1989) or in a variation of Karnovsky's fixative solution of $4 \%$ paraformaldehyde in $0.05 \mathrm{M}$ phosphate buffer and 4\% aqueous glutaraldehyde, $\mathrm{pH} 7.2$ (Plattnert, 1975).

Material fixed in neutral formaldehyde was dehydrated in an ascending ethanol series, treated with isopropanol, and embedded in Paraplast (Hauser, 1952). Serial sections $6 \mu \mathrm{m}$ thick were stained with Goldner's Masson, Heidenhain's AZAN or Cason's Mallory (Romeis, 1989). To obtain better staining reactions, dewaxed sections were submitted to mordanting with SUSA's fixative (Romeis, 1989) for three hours. Additional material was also submitted to some histochemical reactions for identification of the secretion: Alcian blue/Periodic Acid Schiff (AB/PAS) (Romeis, 1989), Bonhag's bromophenol blue (Pearse, 1968), Yasuma \& Itchikawa's Ninhydrin (Pearse, 1968) and Adams's DMAB (Romeis, 1989).

Material fixed in paraformaldehyde/ glutaraldehyde was washed in Sörensen's phosphate buffer (Ruthmann, 1966), dehydrated in an ascending ethanol series and embedded in HISTORESIN (Reichert-Jung). Sections $6 \mu \mathrm{m}$ thick were stained with methylene blue and basic fuchsine (Bennett et al., 1976) or toluidine blue (Spurlock et al., 1966).

Measurements were made by means of a calibrated eyepiece micrometer on material fixed in paraformaldehyde/glutaraldehyde and embedded in HISTORESIN.

\section{RESULTS}

The penial glands of Girardia biapertura have their cell body located in the mesenchyme between the penis bulb and the copulatory bursa. Four types of secretory cells are distinguished (see Fig. 1). Their long cell necks open directly into the male atrium through the epithelium of the penis papilla or into the ducts which traverse the penis bulb and penis papilla (= intrabulbar vasa deferentia) which were here named intrapenial ducts. They are lined by a columnar epithelium whereas the sperm ducts show a cuboidal or 
squamous lining. The latter, by penetrating the penial bulb, narrow and open into the spacious intrapenial ducts.

The distal portions of the cell necks of the secretory cells of type I are abundant in the penis bulb and open into the proximal portion of the intrapenial ducts (see Figs. 2-3), i.e., just distal to the opening of the sperm ducts into the intrapenial ducts. The cell bodies show a conspicuous nucleus (see Table 1) and the secretory granules (approx. $1.5 \mu \mathrm{m}$ in diameter) are of a proteinaceous nature, according to the results of the trichrome methods and the positive reaction to DMAB (as shown in Fig. 4 and Table 1).

The secretory cells of type II (see Figs. 3 and 5) may open between the secretory cells of type I, but they mainly open in the median portion of the intrapenial ducts. The fine secretory granules (approx. $0.4 \mu \mathrm{m}$ in diameter) react weakly to PAS, indicating that the secretion is constituted of neutral mucopolyssacharides (as shown in Table 1).

Type III secretory cells (see Fig. 7) discharge their secretion into the distal portion of the intrapenial ducts, i.e., in the vicinity of the openings of these ducts into the male atrium, as well as directly into the male atrium through the epithelium of the penis papilla (see Fig. 1). Their amorphous secretion stains strong positively to PAS and DMAB and negatively to Ninhydrin (as shown in Table 1), indicating a glycoproteic nature.

The secretory cells of type IV open into the distal portion of the intrapenial ducts and directly into the male atrium through the epithelium of the penis papilla (as shown in Figs. 1 and 8). The small cell body (see Fig. 9) and the cell neck are filled with secretory granules (1.2 $\mu \mathrm{m}$ in diameter) containing a mucous secretion constituted by glycosaminoglycans (see Table 1).

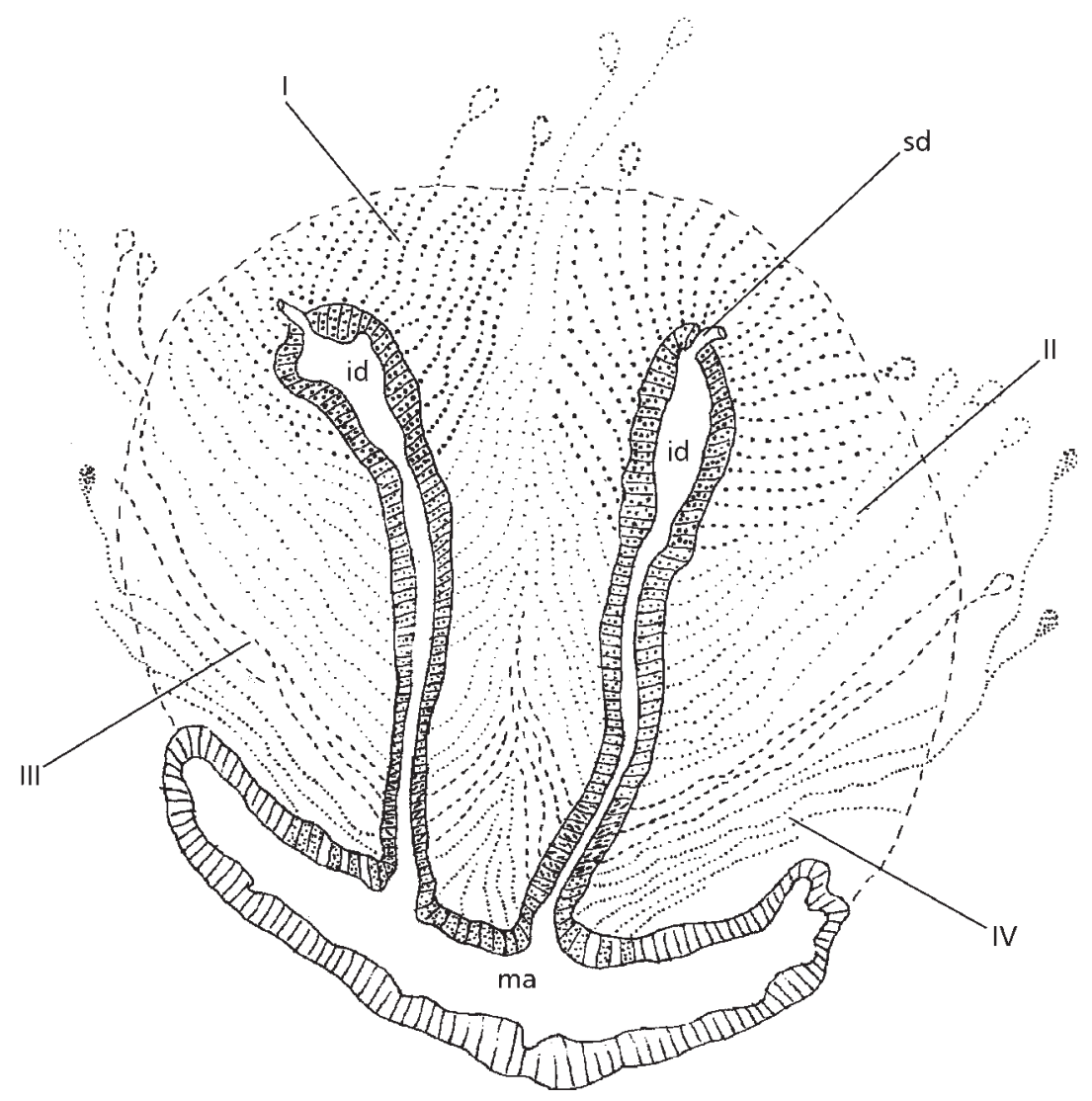

Fig. 1 - Diagram of the penis bulb and penis papilla of Girardia biapertura showing the openings of the penial glands. I: type I secretory cells, II: type II secretory cells, III: type III secretory cells, IV: type IV secretory cells, id: intrapenial ducts, ma: male atrium, and sd: sperm ducts. 


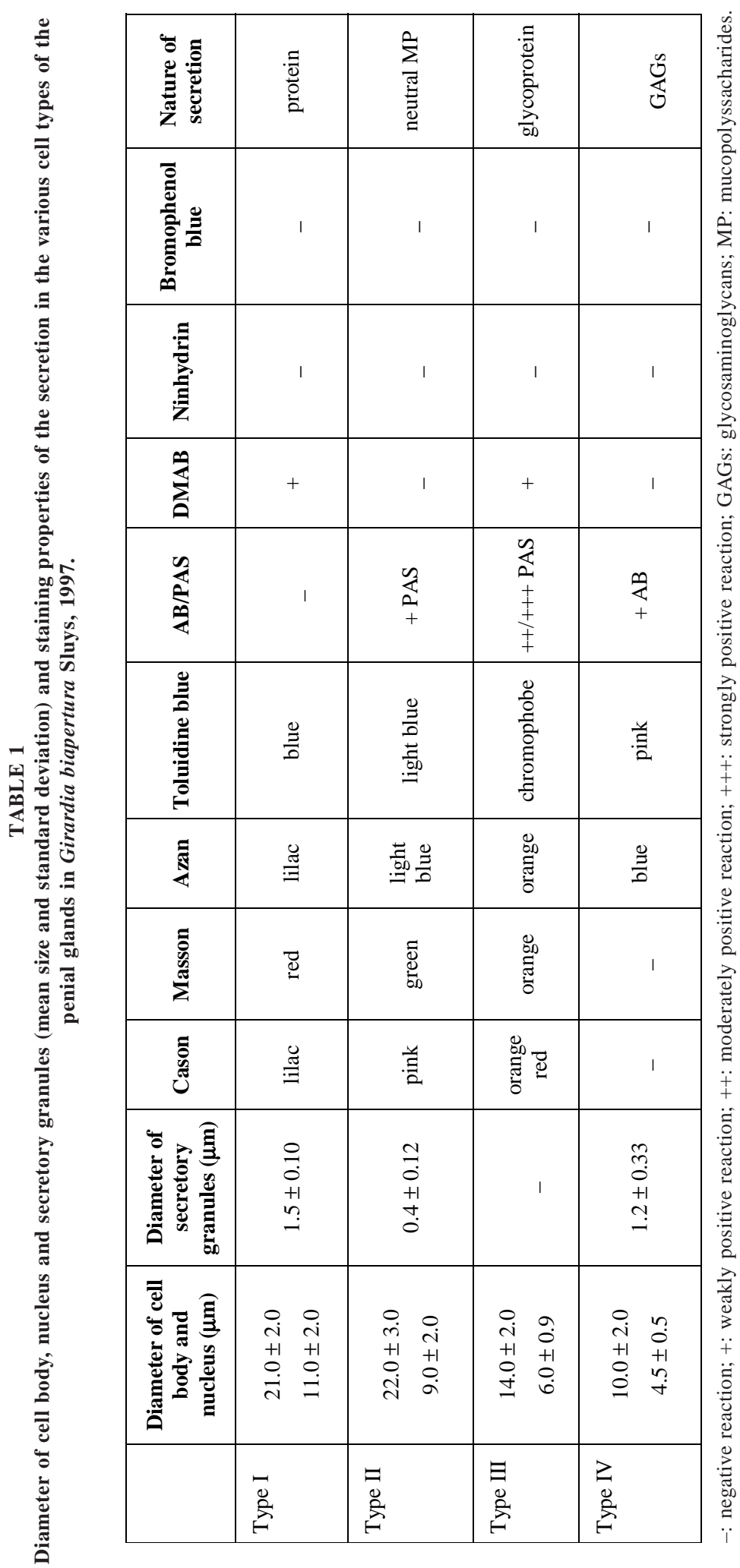




\section{DISCUSSION}

According to Sluys et al. (1997), in G. biapertura the vasa deferentia penetrate the lateral portions of the penis bulb and thereafter expand to form spacious ducts that open separately at the tip of the penis papilla. In the present work we use the term intrapenial ducts for these intrabulbar and intrapapillar canals, since they are histologically distinguished from the sperm ducts by having a characteristic lining and receiving the penial glands. Sluys et al. (1997) mentioned that numerous erythrophil secretory cells open into these intrapenial ducts and may discharge their secretion also through the epithelium of the penis papilla. However, these authors did not distinguish between the various secretory cell types as described in this paper.

Although the intrapenial ducts of $G$. biapertura do not present any anatomical differentiation, excepting a somewhat expanded proximal part, the distribution of the openings of the secretory cells which compose the penial glands allows for the differentiation of three regions: proximal, median and distal. The location of the first-mentioned section in the penis bulb and its expanded form suggest that it is homolog to the bulbar cavity of other freshwater planarians. The proteinaceous secretion of type I secretory cells in G. biapertura, containing tryptophane and reacting negatively to Ninhydrin and Bromophenol blue, differentiates this cell type from that discharging into the bulbar cavity of $G$. schubarti, which shows a proteinaceous secretion positive to Bromophenol blue (Leal-Zanchet \& Hauser, 1999).

The median and distal portions of the intrapenial ducts in $G$. biapertura may correspond to the ejaculatory duct of other triclads. They receive three types of secretions. The secretory cells of type II, opening mainly into the median region, produce a mucous secretion (neutral mucopolyssacharides). The other two cell types (types III and IV), discharging into the distal part of the ducts, produce glycoprotein and glycosaminoglycans, respectively. In G. schubarti, three cell types were observed opening into the ejaculatory duct, producing a proteinaceous, mucous and glycoproteic secretion, respectively (Leal-Zanchet \& Hauser, 1999). For G. bonaerensis, Moretto (1996) mentioned a single type of secretory cell containing basic protein opening along the entire length of the ejaculatory duct.

The cell types III and IV of G. biapertura also penetrate the epithelium of the penis papilla, in the vicinity of the openings of the intrapenial ducts. These restricted distribution of secretory cells differentiate $G$. biapertura from other species of Girardia which show secretory cells opening throughout the entire surface of the penis papilla (Kawakatsu et al., 1984a, b; Sluys, 1992; LealZanchet \& Hauser, 1999).

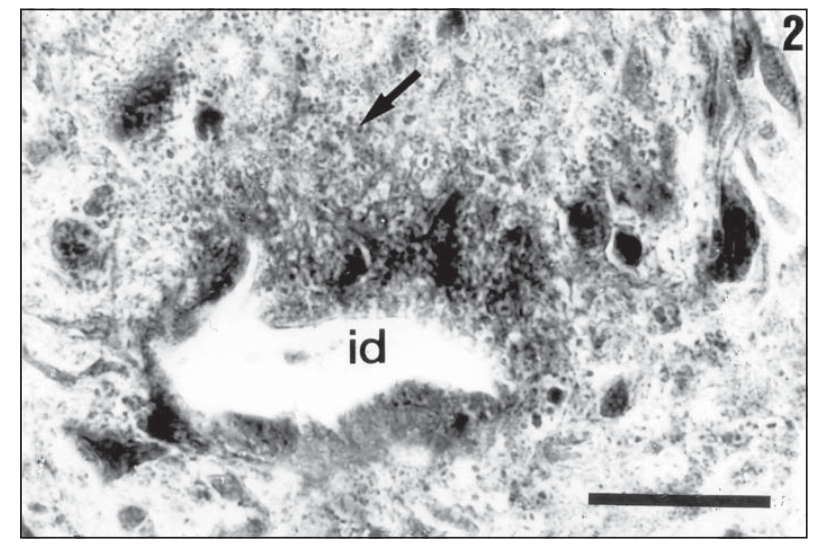

Fig. 2 - Proximal portion of the intrapenial duct (id) of Girardia biapertura. Sagittal section stained with Masson/Goldner. Scale bar, $20 \mu \mathrm{m}$. Arrow indicates granules of type I secretory cells. 


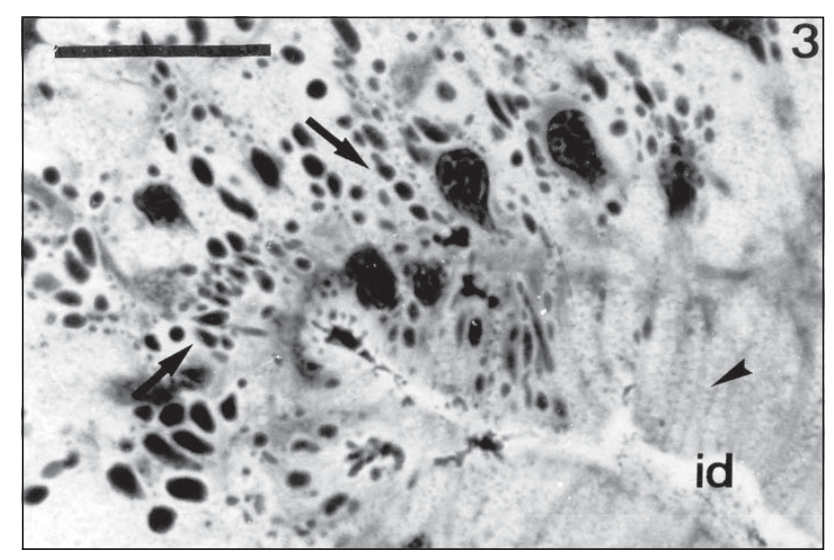

Fig. 3 - Transition from the proximal to the median portion of the intrapenial duct (id) of Girardia biapertura. Sagittal section stained with toluidine blue. Scale bar, $40 \mu \mathrm{m}$. Arrows indicate granules of type I secretory cells, the arrow head shows the distal portion of necks of type II secretory cells.

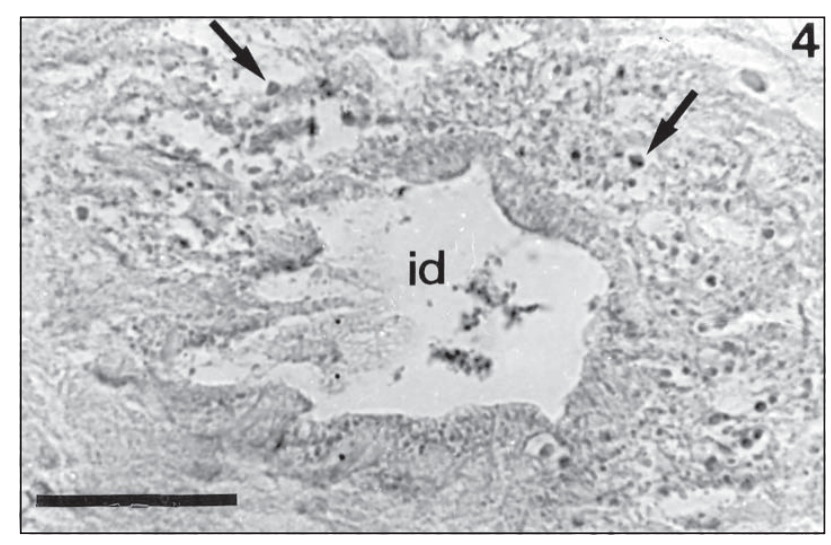

Fig. 4 - Proximal portion of the intrapenial duct (id) of Girardia biapertura. Sagittal section stained with DMAB. Scale bar, $40 \mu \mathrm{m}$. Arrows indicate granules of type I secretory cells.

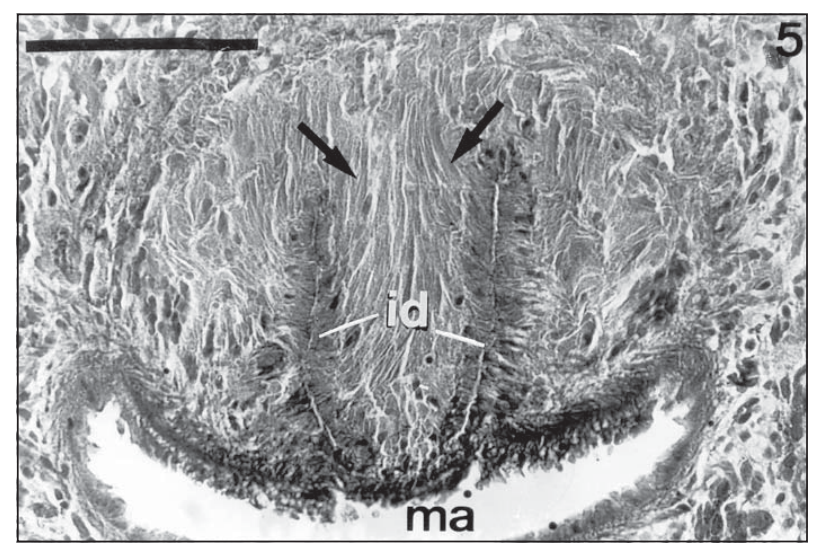

Fig. 5 - Penis bulb and penis papilla of Girardia biapertura showing median and distal portions of the intrapenial ducts (id). Horizontal section stained with Cason to show the distal portion of necks of type II secretory cells (arrows). Scale bar, $150 \mu \mathrm{m}$. ma: male atrium. 


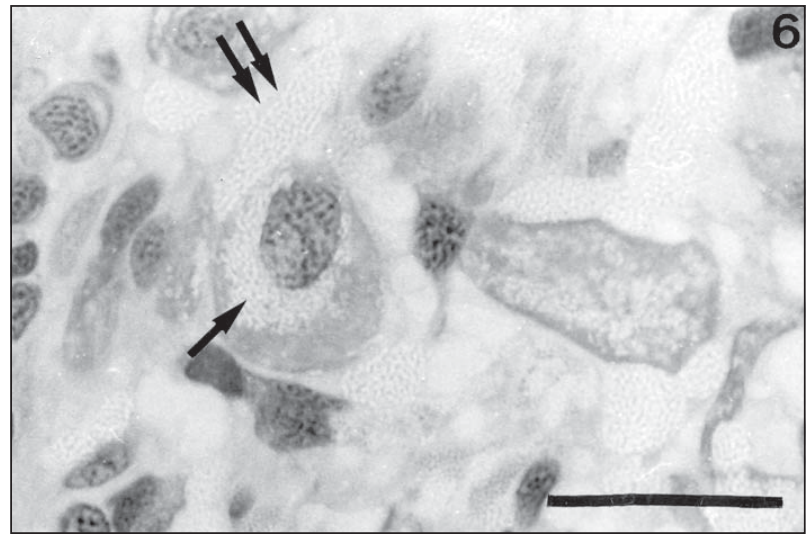

Fig. 6 - Cell body and proximal part of cell neck (double arrow) of type II secretory cell. Horizontal section stained with toluidine blue. Scale bar, $30 \mu \mathrm{m}$. Arrow indicates secretory granules.

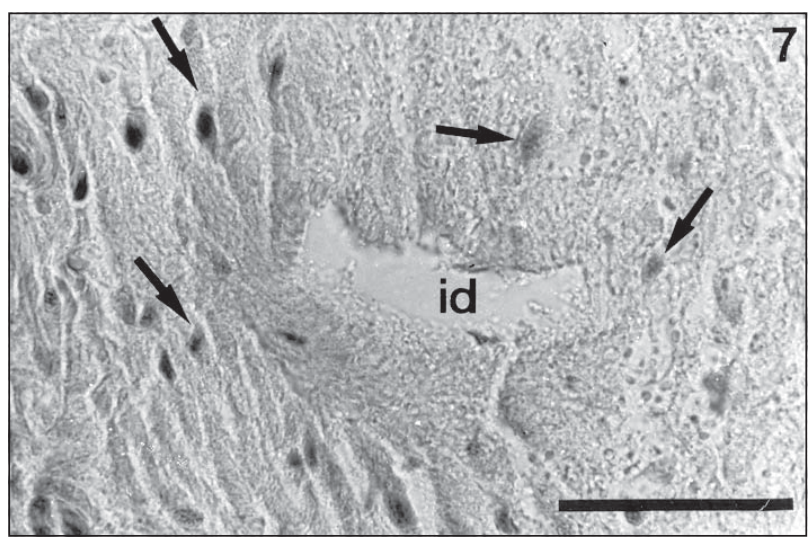

Fig. 7 - Transition from the median to distal portion of the intrapenial duct (id) of Girardia biapertura. Sagittal section stained with AB/PAS. Scale bar, $50 \mu \mathrm{m}$. Arrows indicate type III secretory cells.

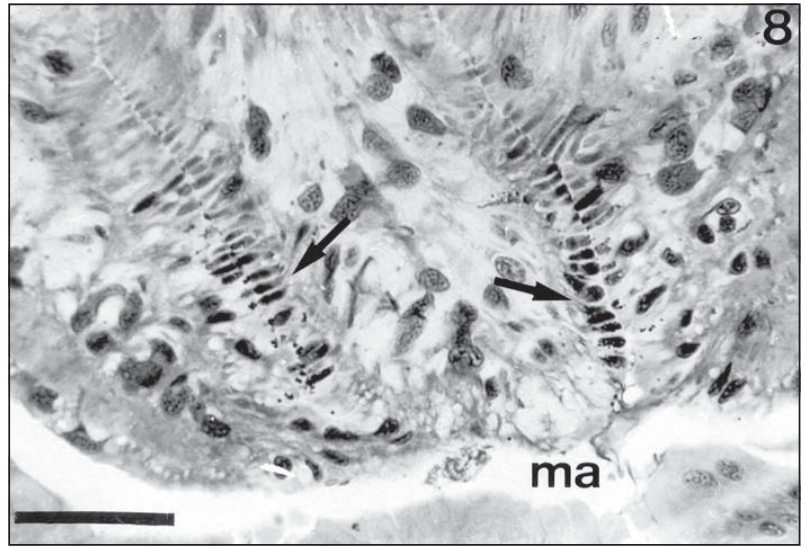

Fig. 8 - Distal portion of the penis papilla of Girardia biapertura. Horizontal section stained with toluidine blue. Scale bar, $50 \mu \mathrm{m}$. Arrows indicate type IV secretory cells. ma: male atrium. 


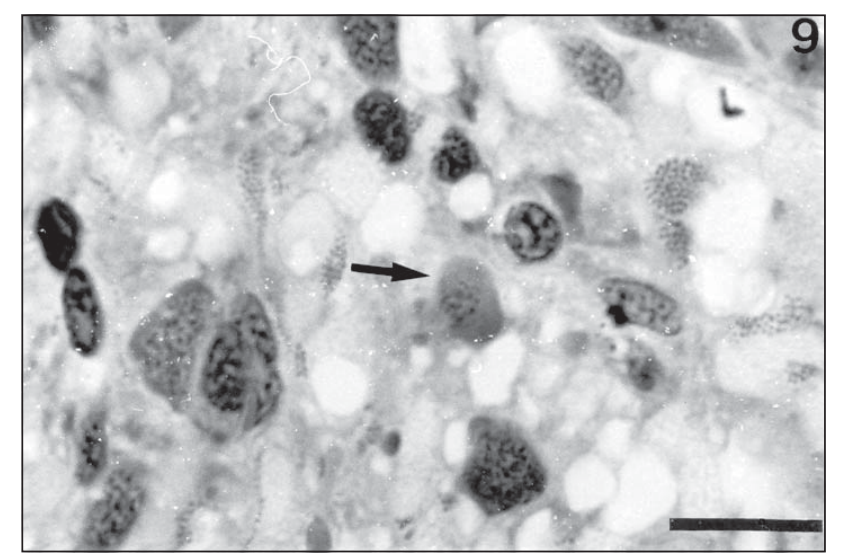

Fig. 9 - Cell body (arrow) of type IV secretory cell. Horizontal section stained with toluidine blue. Scale bar, $20 \mu \mathrm{m}$.

According to Sluys (1992), who studied several species of Girardia, characterisation of the glands of the female copulatory apparatus may contribute important taxonomic characters. Comparison of results obtained by Fischlschweiger (1990), Moretto (1996), Leal-Zanchet \& Hauser (1999), as well as unpublished observations on other Girardia species, and results presented here suggests that histological/histochemical analysis of penial glands may also provide features useful in the characterisation of species of Girardia in particular and perhaps of freshwater planarians in general.

Acknowledgments - The authors thank Dr. Ronald Sluys, Dr. Ernest Schockaert and Dr. Leigh Winsor for comments and suggestions made on an early draft of this paper and Dr. Josef Hauser for a critical reading. The Brazilian Council for Scientific and Technological Development $(\mathrm{CNPq})$ is acknowledged for the fellowship gave to S.T.S. (PIBIC/CNPq) and the Fundação de Amparo à Pesquisa do Rio Grande do Sul (FAPERGS) for financial support.

\section{REFERENCES}

BALL, I. R., 1974, A contribution to the phylogeny and biogeography of the freshwater triclads (Platyhelminthes, Turbellaria). In: N. W. Riser \& M. P. Morse (eds.), Biology of the Turbellaria. McGraw Hill, New York, pp. 339-401.

BENNETT, H. S., WYRICK, A. D., LEE, S. W. \& MCNEIL, J. H., 1976, Science and art preparing tissues embedded in plastic for microscopy, with special reference to glycol methacrylate, glass knives and simple stains. Stain technol., 51(2): 71-97.
FISCHLSCHWEIGER, W., 1990, Ultrastructure of the sperm duct and penis bulb of Dugesia tigrina (Platyhelminthes: Tricladida). Trans. Am. Microsc. Soc., 109: 141-151.

FISCHLSCHWEIGER, W. \& CLAUSNITZER, E., 1984, Bursa, bursa canal, and female atrium of Dugesia tigrina (Platyhelminthes: Tricladida). Zoomorphology, 104: 386395.

HAUSER, J., 1952, Ausschaltung des Xylols in der histologischen Technik. Mikroskopie, 7(5-6): 208-209.

KAWAKATSU, M., HAUSER, J., FRIEDRICH, S. M. G. \& SOUZA LIMA, O., 1982, Morphological, karyological and taxonomic studies of freshwater planarians from South Brazil. III. Dugesia tigrina (Girard, 1850) and Dugesia schubarti (Marcus, 1946) from the vicinities of São Carlos, Estado de São Paulo (Turbellaria, Tricladida, Paludicola). Bull. Fuji Women's Coll., Ser II, 20: 73-90.

KAWAKATSU, M., HAUSER, J. \& FRIEDRICH, S. M. G., 1983a, Morphological, karyological and taxonomic studies of freshwater planarians from South Brazil. V. Dugesia tigrina (Girard, 1850) from Município de Botucatu, Estado de São Paulo, and Dugesia schubarti (Marcus, 1946) from the vicinity of São Leopoldo (Turbellaria, Tricladida, Paludicola). Bull. Fuji Women's Coll., Ser II, 21: 147-163.

KAWAKATSU, M., HAUSER, J. \& FRIEDRICH, S. M. G., 1983b, Morphological, karyological and taxonomic studies of freshwater planarians from South Brazil. IV. Dugesia anderlani sp. nov. (Turbellaria, Tricladida, Paludicola), a new species from São Leopoldo in Estado de Rio Grande do Sul. Annot. Zool. Jap., 56(3): 196-208.

KAWAKATSU, M., HAUSER, J. \& FRIEDRICH, S. M. G., 1985, Morphological, karyological and taxonomic studies of freshwater planarians from South Brazil. VII. Supplementary notes on Dugesia schubarti (Marcus, 1946) from the vicinity of São Leopoldo (Turbellaria, Tricladida, Paludicola). Bull. Fuji Women's Coll., Ser II, 23: 101-109. 
KAWAKATSU, M., HAUSER, J. \& FRIEDRICH, S. M. G., 1986, Morphological, karyological and taxonomic studies of freshwater planarians from South Brazil. VIII. Four Dugesia species (D. tigrina, D. schubarti, D. anderlani and D. arndti) collected from several localities in Estado de Rio Grande do Sul (Turbellaria, Tricladida, Paludicola). Bull. Fuji Women's Coll., Ser II, 24: 41-62.

KAWAKATSU, M., MITCHEL, R. W. \& KISHIDA, Y., 1984a, A freshwater planarian from Central Peru collected by the members of Kanazawa University Expedition into the Peruvian Andes: Dugesia rincona Marcus, 1954 (Turbellaria, Tricladida, Paludicola). Biol. Inland Waters, 3: 1-18.

KAWAKATSU, M., OKI, I., TAMURA, S., YAMAYOSHI, T., HAUSER, J. \& FRIEDRICH, S. M. G., 1984b, Morphological, karyological and taxonomic studies of freshwater planarians from South Brazil. VI. Dugesia schubarti (Marcus, 1946) from the vicinity of São Leopoldo, Estado de Rio Grande do Sul (Turbellaria, Tricladida, Paludicola). Bull. Fuji Women's Coll., Ser II, 22: 45-62.

LEAL-ZANCHET, A. M. \& HAUSER, J., 1999, Penis glands of the dugesiid planarian Girardia schubarti (Platyhelminthes, Tricladida, Paludicola). Invert. Biol., 118(1): 3541.

MORETTO, H. J. A., 1996, La planaria chilena Dugesia sanchezi (Platyhelminthes: Turbellaria) y Dugesia bonaerensis n. sp., planaria de la pampa húmeda de Buenos Aires, Argentina. Rev. Chil. Hist. Nat., 69: 213-230.
PEARSE, A. G. E., 1968, Histochemistry theoretical and applied. J. \& A. Churchill Ltd, London, 759p.

PLATTNERT, N., 1975, Die chemische Fixierung biologischer Objekte für die Eletronenmikroskopie. In: G. Schimmel \& W. Vogell (eds.), Methodensammlung der Elektronenmikroskopie. Wissenschaftliche Verlagsgesellschaft mbH, Stuttgart, pp. 39-40.

ROMEIS, B., 1989, Mikroskopische technik. Urban und Schwarzenberg, München, 697p.

RUTHMANN, A., 1966, Methoden der zellforschung. Franckh'sche Verlagshandlung, Stuttgart, pp. 276-277.

SLUYS, R., 1992, Synopsis of the freshwater triclads of the Caribbean (Platyhelminthes, Tricladida, Paludicola). Stud. Nat. Hist. Caribb. Region, 71: 1-23.

SLUYS, R., 1996, Reconsiderations of the species status of some South American Planarians (Platyhelminthes: Tricladida: Paludicola). Proc. Biol. Soc. Washington, 109(2): 229-235.

SLUYS, R., HAUSER, J. \& WIRTH, Q. J., 1997, Deviation from the Groundplan: a unique new species of freshwater planarian from South Brazil (Platyhelminthes, Tricladida, Paludicola). J. Zool., 241: 593-601.

SPURLOCK, B. O., SKINNER, M. S. \& KATTINE, A. A. 1966, Simple rapid method for staining epoxi-embedded specimens for light microscopy with the polichromatic staining Paragon-1031. Am. J. Clin. Pathol., 46: 252-258. 